\title{
Psychological Issues in Managing Families with Inherited Cardiovascular Diseases
}

\author{
Jodie Ingles ${ }^{1,2,3}$ \\ ${ }^{1}$ Agnes Ginges Centre for Molecular Cardiology at Centenary Institute, The University of Sydney, Newtown, \\ New South Wales NSW 2042, Australia \\ ${ }^{2}$ Faculty of Medicine and Health, The University of Sydney, Sydney, New South Wales NSW 2000, Australia \\ ${ }^{3}$ Department of Cardiology, Royal Prince Alfred Hospital, Camperdown, New South Wales NSW 2050, Australia \\ Correspondence: j.ingles@centenary.org.au
}

The field of cardiovascular genetic counseling has evolved dramatically in recent years largely to manage the unique psychological needs of the inherited cardiovascular disease patient population. For many, there can be difficulty in coming to terms with a diagnosis, whether it be adjusting to lifestyle recommendations such as exclusion from competitive sports or living with a small but remarkable risk of sudden cardiac death. For those considered at risk of life-threatening ventricular arrhythmias, the decision to have an implantable cardioverter defibrillator can be difficult. Living with the device, especially for those who are young and those who receive multiple shocks, can precipitate psychological distress and poor adaptation to the device. Family members who experience a sudden cardiac death of a young relative have a significant risk of poor psychological outcomes. The roles of the cardiac genetic counselor in facilitating patients' adaptation to their diagnoses and management and recognizing when additional support from a clinical psychologist is needed are key to ensuring families receive the best possible care.

nherited cardiovascular diseases can affect all aspects of the heart. They include cardiomyopathies, arrhythmia syndromes, and metabolic and connective tissue diseases, as well as numerous other genetic syndromes that can present with cardiac manifestations (Fig. 1). As a result, the field of cardiac genetic counseling has rapidly emerged as a growing subspecialty. Sudden cardiac death is a rare but tragic outcome among those with inherited cardiovascular diseases. Managing the risk of a future sudden cardiac death can add layers of complexity to more traditional genetic counseling roles. For example, eliciting a family history from a patient newly diagnosed and told to consider an implantable cardioverter defibrillator by their cardiologist for prevention of fatal arrhythmias will be challenging. Likewise, explaining inheritance risks and undertaking pretest genetic counseling will not be straightforward for a family that have recently come to medical attention because of the sudden cardiac death of a young and otherwise healthy relative. In many cases, the pressing concern is making sense of the situation that confronts them. Providing information about their cardiovascular disease and management,

Editors: Laura Hercher, Barbara Biesecker, and Jehannine C. Austin

Additional Perspectives on Genetic Counseling: Clinical Practice and Ethical Considerations available at

www.perspectivesinmedicine.org

Copyright (C) 2020 Cold Spring Harbor Laboratory Press; all rights reserved; doi: 10.1101/cshperspect.a036558

Cite this article as Cold Spring Harb Perspect Med 2020;10:a036558 


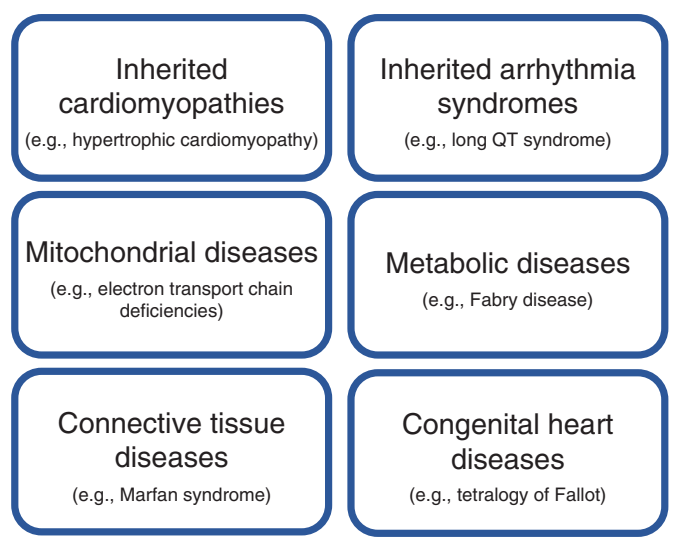

Figure 1. Inherited cardiovascular diseases.

and heritability, in combination with psychotherapeutic counseling are key skills for a cardiac genetic counselor. Counselors need to be as comfortable discussing the psychological aspects of adjusting to an implantable cardioverter defibrillator as they would be discussing inheritance risks. Counseling skills to sensitively convey important information while attending to patients' and families' psychological responses are roles that define cardiac genetic counselors as key partners in a specialized multidisciplinary team. This review aims to describe the psychological issues frequently encountered by patients and family members with inherited cardiovascular diseases, specifically inherited cardiomyopathies and arrhythmia syndromes, and to demonstrate the vital role of cardiac genetic counseling in patient care.

\section{ASSIMILATING DIAGNOSIS OF AN INHERITED CARDIOVASCULAR DISEASE}

Cardiovascular disease remains the leading cause of death in the United States (Benjamin et al. 2019), often occurring in the elderly population, with environmental factors that include lifestyle choices that contribute to disease risk and development (McGovern et al. 1996). In contrast, patients with inherited cardiovascular diseases often present with symptoms in childhood, adolescence, and early adulthood, and the cause is largely due to a gene variant that is inherited in an autosomal-dominant pattern.
Many patients with inherited cardiovascular diseases have only minimal cardiac symptoms and yet are required to make significant lifestyle adjustments to live with an elevated risk of developing the most serious outcomes: heart failure and sudden cardiac death. As such, adaptation to the diagnosis of a hereditary cardiovascular disease can be a challenging long-term process for patients and their families.

Collectively, hereditary cardiovascular diseases present similar genetic counseling issues. Adaptation to a diagnosis of any of these conditions at a young age, and specifically in cases in which there is little, if any, experience living with the disease in the family, can be challenging in many ways. There is a need to make sense of this new health threat, considering the prognostic and management information provided by the clinical team, which may require commencement of medications despite feeling well. Periodic follow-up with a cardiologist is indicated, and because of the risk of sudden cardiac death, some patients undergo prophylactic implantable cardioverter defibrillator (ICD) therapy. Other complications more frequently encountered are development of atrial fibrillation and progression to heart failure, in some instances requiring cardiac transplant. Cardiac symptoms frequently reported by patients include chest pain, shortness of breath on exertion, dizziness (presyncope), blackouts (syncope), and palpitations. For many patients with one of these conditions, there will be few if any cardiac symptoms. Clinicians' ability to predict who will experience poor clinical outcomes is limited. Even within a family, it is common to see the full phenotypic range expressed among relatives. In most cases, having a severely affected family member does not mean that other relatives will be similarly affected. For patients, direct experience with the disease will significantly affect perceptions about prognosis (Ormondroyd et al. 2014; Connors et al. 2015). As such, learning of this variability in the clinical course and uncertainty about the progression of disease can be difficult.

Hereditary arrhythmia syndromes often present in childhood and adolescence, with sudden onset of arrhythmias leading to symptoms 
like palpitations, dizziness, and syncope (Priori et al. 2015). They present with a greater risk of ventricular arrhythmias that can result in sudden cardiac death. Taking a family history from patients with hereditary arrhythmia syndromes will often reveal significant cardiac events among relatives, such as frequent "fainters," sudden infant death syndrome (SIDS), and epilepsy diagnoses, and, importantly, fatal ventricular arrhythmias can be misattributed to other causes if they occur while driving (motor vehicle accident) or swimming (drowning). Attention to the details of any young deaths in the family is critical to determining whether there may have been an underlying cardiac cause. Eliciting this information from the family can stir up feelings of grief and loss, and it can be evident that there is significant anxiety about the risk to other relatives, especially children (Ormondroyd et al. 2014; Burns et al. 2016). In contrast, hereditary cardiomyopathies typically present later in life, from teenage years through to adulthood, and will often result in cardiac-limiting symptoms, such as chest pain and shortness of breath at some point during life (Watkins et al. 2011). The impact on physical health-related quality of life is thus an important consideration for this group. Historical physical activity recommendations have further compounded this issue, with many patients ceasing to do any form of physical activity because of the perceived risk of sudden cardiac death (Sweeting et al. 2016).

\section{RESEARCH FINDINGS}

Numerous studies have assessed self-reported psychological outcomes or explored perceptions following diagnosis of a hereditary cardiovascular disease. Research that has generated evidence to help shape the field is presented in Table 1. In one of the largest quantitative studies, healthrelated quality of life was assessed in more than 400 individuals with inherited cardiovascular diseases, including both affected patients and at-risk relatives (Ingles et al. 2013b). Among those with inherited cardiomyopathies such as hypertrophic cardiomyopathy (HCM) and dilated cardiomyopathy (DCM), there was lower physical quality of life, whereas mental quality of life was generally maintained. In those participants with long QT syndrome (LQTS), psychological quality of life was reduced compared to rates in the general population. These significant differences between hereditary cardiomyopathies and hereditary arrhythmia syndromes have been reported by others, and likely relate to the differences between the disease profile among the two groups (Table 1).

Medications are recommended for many patients with inherited cardiovascular diseases, especially for those with arrhythmia syndromes. For young patients, adherence to $\beta$-blocker medication can be strongly influenced by psychological and social factors (Ingles et al. 2015; O'Donovan et al. 2018). In the setting of LQTS, $\beta$-blocker therapy is shown to reduce the likelihood of cardiac arrhythmias and is an important first-tier treatment (Chockalingam et al. 2012). Arrhythmias while taking a $\beta$-blocker can signal the need for additional therapy such as an ICD. In the medical literature, studies of adherence to any prescribed therapy indicate that psychological factors, including illness perception, beliefs about the medication, self-efficacy (i.e., their confidence in their ability to take the medication), and psychosocial well-being, are important determinants of medication adherence (Jin et al. 2008). One study examining adherence to $\beta$-blocker therapy among patients with LQTS found $16 \%$ were not adherent (O'Donovan et al. 2018). Those who were younger and had an inherited arrhythmia syndrome reported lower self-efficacy, greater concerns, low necessity beliefs, and poorer understanding of their disease. Importantly, they were also less likely to take their prescribed $\beta$-blocker medication. Another study investigating self-reported medication adherence among patients with HCM found that $30 \%$ were nonadherent and more likely to be from a minority ethnicity with self-reported anxiety symptoms (Ingles et al. 2015). These studies provide evidence of the need for genetic counseling interventions to uphold adherence to prescribed medical therapy. This may be an achievable goal of genetic counseling. Targets of the interventions may be affirming beliefs about the cardioprotective role of the medica- 
J. Ingles

Table 1. Key studies investigating the psychological and social impact of living with an inherited cardiovascular disease

\begin{tabular}{|c|c|c|c|c|}
\hline Study & $\begin{array}{l}\text { Disease } \\
\text { setting }\end{array}$ & Study design & Psychosocial measures & Key findings \\
\hline $\begin{array}{l}\text { Bates et al. } \\
2019\end{array}$ & $\begin{array}{l}\text { SCD in } \\
\text { the } \\
\text { young }\end{array}$ & $\begin{array}{l}N=33 \text { first-degree } \\
\text { relatives following a } \\
\text { SCD of a young } \\
\text { relative and no } \\
\text { premorbid diagnosis }\end{array}$ & $\begin{array}{l}\text { Hospital anxiety and } \\
\text { depression scale } \\
\text { (HADS), psychological } \\
\text { adaptation to genetic } \\
\text { information scale } \\
\text { (PAGIS), impact of } \\
\text { events scale-revised } \\
\text { (IES-R), } \\
\text { multidimensional scale } \\
\text { of perceived social } \\
\text { support (MSPSS) }\end{array}$ & $\begin{array}{l}\text { More than one-third } \\
\text { reported poor } \\
\text { adaptation to genetic } \\
\text { information following } \\
\text { the postmortem } \\
\text { molecular autopsy. } \\
\text { Those with poor } \\
\text { adaptation were more } \\
\text { likely to have } \\
\text { posttraumatic stress } \\
\text { symptoms, depression, } \\
\text { lower perceived social } \\
\text { support, and support } \\
\text { from significant others, } \\
\text { family members, and } \\
\text { friends. }\end{array}$ \\
\hline $\begin{array}{l}\text { Ingles et al. } \\
2016\end{array}$ & $\begin{array}{l}\text { SCD in } \\
\text { the } \\
\text { young }\end{array}$ & $\begin{array}{l}N=103 \text { first-degree } \\
\text { relatives following a } \\
\text { SCD of a young } \\
\text { relative and no } \\
\text { premorbid diagnosis }\end{array}$ & $\begin{array}{l}\text { Short Form Health Survey } \\
\text { (SF-36), depression } \\
\text { anxiety stress scale } \\
\text { (DASS-21), IES-R, } \\
\text { prolonged grief disorder } \\
\text { scale }\end{array}$ & $\begin{array}{l}\text { Prolonged grief was } \\
\text { reported by } 21 \% \text { ( } 36 \% \\
\text { of mothers, } 42 \% \text { of } \\
\text { those who witnessed } \\
\text { the death) and } \\
\text { posttraumatic stress } \\
\text { symptoms reported by } \\
44 \% \text { (59\% of mothers, } \\
67 \% \text { of those who } \\
\text { witnessed the death). } \\
\text { Overall almost } 50 \% \text { of } \\
\text { relatives reported } \\
\text { symptoms requiring } \\
\text { intervention with a } \\
\text { clinical psychologist, } \\
\text { on average } 6 \text { yr after the } \\
\text { death. }\end{array}$ \\
\hline $\begin{array}{r}\text { van der Werf } \\
\text { et al. } 2014\end{array}$ & $\begin{array}{l}\text { SCD in } \\
\text { the } \\
\text { young }\end{array}$ & $\begin{array}{l}N=9 \text { first-degree } \\
\text { relatives or spouses; } \\
\text { semistructured } \\
\text { interviews, analyzed } \\
\text { thematically }\end{array}$ & $\begin{array}{l}\text { Qualitative thematic } \\
\text { analysis of interview } \\
\text { transcripts }\end{array}$ & $\begin{array}{l}\text { There was a strong need to } \\
\text { understand the cause of } \\
\text { the death and wanting } \\
\text { to prevent future deaths } \\
\text { in their family. The } \\
\text { current } \\
\text { multidisciplinary clinic } \\
\text { model was appreciated, } \\
\text { although ways to } \\
\text { improve information } \\
\text { processes and better } \\
\text { support of decision- } \\
\text { making were deemed } \\
\text { important. }\end{array}$ \\
\hline
\end{tabular}


Psychological Issues with Inherited Cardiovascular Diseases

Table 1. Continued

\begin{tabular}{|c|c|c|c|c|}
\hline Study & $\begin{array}{l}\text { Disease } \\
\text { setting }\end{array}$ & Study design & Psychosocial measures & Key findings \\
\hline $\begin{array}{l}\text { Ingles et al. } \\
2013 \mathrm{~b}\end{array}$ & $\begin{array}{l}\text { HCM, } \\
\text { DCM, } \\
\text { ARVC, } \\
\text { LQTS, } \\
\text { CPVT }\end{array}$ & $\begin{array}{l}N=409 \text { participants } \\
\quad \text { (affected and at-risk } \\
\text { relatives); cross- } \\
\text { sectional self-report } \\
\text { survey }\end{array}$ & SF-36 & $\begin{array}{l}\text { Physical component } \\
\text { scores were impaired } \\
\text { for patients with HCM, } \\
\text { DCM, and CPVT. } \\
\text { Mental component } \\
\text { scores were impaired in } \\
\text { those with LQTS. In } \\
\text { HCM, predictors of } \\
\text { poor physical } \\
\text { component scores were } \\
\text { female gender, } \\
\text { comorbidities, and } \\
\text { higher NHYA } \\
\text { functional class. }\end{array}$ \\
\hline $\begin{array}{l}\text { James et al. } \\
2012\end{array}$ & ARVC & $\begin{array}{l}N=86 \text { adults with } \\
\text { ARVC and an ICD }\end{array}$ & $\begin{array}{l}\text { Florida shock anxiety scale } \\
\text { (FSAS), Florida patient } \\
\text { acceptance survey } \\
\text { (FPAS), Duke activity } \\
\text { status index, HADS }\end{array}$ & $\begin{array}{l}\text { Overall device acceptance } \\
\text { was normative; } \\
\text { however, there were } \\
\text { marked body image } \\
\text { concerns, particularly } \\
\text { among younger } \\
\text { patients. Younger } \\
\text { patients also had } \\
\text { greater device-specific } \\
\text { anxiety. Those who } \\
\text { showed poor } \\
\text { adjustment to their } \\
\text { device were more likely } \\
\text { to have anxiety and } \\
\text { depression. }\end{array}$ \\
\hline $\begin{array}{l}\text { Hamang } \\
\text { et al. } 2010\end{array}$ & $\begin{array}{l}\text { HCM, } \\
\text { LQTS }\end{array}$ & $\begin{array}{l}N=127 \text { (affected and at- } \\
\text { risk relatives); cross- } \\
\text { sectional self-report } \\
\text { survey }\end{array}$ & SF-36 & $\begin{array}{l}\text { All participants had } \\
\text { impaired general health } \\
\text { scores compared to the } \\
\text { general population. } \\
\text { Employment, higher } \\
\text { education, and referral } \\
\text { to genetic counseling } \\
\text { through a family } \\
\text { member were } \\
\text { associated with } \\
\text { improved health status. }\end{array}$ \\
\hline $\begin{array}{l}\text { Christiaans } \\
\text { et al. } 2009\end{array}$ & $\mathrm{HCM}$ & $\begin{array}{l}N=228 \text { (gene-positive } \\
\quad \text { relatives, affected and } \\
\text { unaffected) }\end{array}$ & $\begin{array}{l}\text { SF-36, HADS, revised } \\
\text { version of Illness } \\
\text { Perception } \\
\text { Questionnaire (IPQ-R) }\end{array}$ & $\begin{array}{l}\text { Quality of life and distress } \\
\text { were worse in those } \\
\text { with manifest HCM } \\
\text { compared to those } \\
\text { without. Cardiac } \\
\text { symptoms and a } \\
\text { stronger belief in } \\
\text { consequences of }\end{array}$ \\
\hline
\end{tabular}

Continued 
J. Ingles

Table 1. Continued

\begin{tabular}{|c|c|c|c|c|}
\hline Study & $\begin{array}{l}\text { Disease } \\
\text { setting }\end{array}$ & Study design & Psychosocial measures & Key findings \\
\hline & & & & $\begin{array}{l}\text { carriership were } \\
\text { associated with worse } \\
\text { quality of life. Illness } \\
\text { and risk perception } \\
\text { were major } \\
\text { determinants of quality } \\
\text { of life and distress. }\end{array}$ \\
\hline $\begin{array}{l}\text { Farnsworth } \\
\text { et al. } 2006\end{array}$ & LQTS & $\begin{array}{l}N=31 \text { parents; } \\
\text { qualitative } \\
\text { phenomenological } \\
\text { study; parents of } \\
\text { children with LQTS }\end{array}$ & $\begin{array}{l}\text { Explore fear of death and } \\
\text { quality of life }\end{array}$ & $\begin{array}{l}\text { Parents reported fear of } \\
\text { their child dying and } \\
\text { strategies they used to } \\
\text { manage their fear. } \\
\text { There was frustration } \\
\text { about the lack of LQTS } \\
\text { knowledge from } \\
\text { health-care } \\
\text { professionals. }\end{array}$ \\
\hline $\begin{array}{l}\text { Hendriks } \\
\text { et al. } 2005\end{array}$ & LQTS & $\begin{array}{l}N=36 \text { parents; } \\
\text { longitudinal surveys } \\
\text { and one } \\
\text { semistructured home } \\
\text { interview; parents of } \\
\text { gene carrier children }\end{array}$ & $\begin{array}{l}\text { Impact of events scale } \\
\text { (IES), Spielberger State } \\
\text { Anxiety Inventory } \\
\text { (STAI-s), and Beck } \\
\text { Depression Inventory } \\
\text { (BDI) }\end{array}$ & $\begin{array}{l}\text { Parents of gene carrier } \\
\text { children reported } \\
\text { greater distress than } \\
\text { parents of noncarriers. } \\
\text { Up to one-third } \\
\text { reported clinically } \\
\text { relevant distress. More } \\
\text { distress was reported } \\
\text { among those with } \\
\text { sudden death in the } \\
\text { family. }\end{array}$ \\
\hline
\end{tabular}

(SCD) Sudden cardiac death, (HCM) hypertrophic cardiomyopathy, (DCM) dilated cardiomyopathy, (ARVC) arrhythmogenic right ventricular cardiomyopathy, (LQTS) long QT syndrome, (CPVT) catecholaminergic polymorphic ventricular cardiomyopathy, (NYHA) New York Heart Association, (ICD) implantable cardioverter defibrillator.

tion and their confidence to take it on a regular basis. Challenging unproductive illness and medication perceptions and acknowledging the emotional barriers to adherence have been shown to be beneficial in other settings (Petrie et al. 2012) and may be applied and studied in the care of hereditary cardiovascular syndromes.

\section{RISK OF SUDDEN CARDIAC DEATH}

Adapting to living with a risk of sudden cardiac death affects all patients. Discussing strategies to clinically manage this risk often takes precedence over all other topics in clinic visits, and being considered at increased risk of a ventricular arrhythmia is associated with heightened anxiety and poorer psychological well-being. Patients may be pragmatic about their own risk of sudden cardiac death, although in some cases, there is high anxiety and worry (Ormondroyd et al. 2014). For many, the risk to their children is forefront (Farnsworth et al. 2006). A Dutch study reported parental distress in up to one-third of parents with children who inherited a pathogenic variant for LQTS (Hendriks et al. 2005). Among those with distress, being familiar with the disease for a longer time, experiencing a sudden cardiac death in the family, having a lower formal education, and expressing dissatisfaction with the information provided were each shown to be associated with psychological distress. A qualitative study explored fear 
Psychological Issues with Inherited Cardiovascular Diseases

of sudden cardiac death among parents of children with LQTS (Farnsworth et al. 2006). Parents described coping mechanisms they employed to manage their fear, which included providing children with phones to allow them to check in regularly, using a baby monitor in the child's room at night, and keeping an automatic external defibrillator nearby. Many were involved in increasing awareness of LQTS and ensuring resuscitation action plans were in place in the child's community. Another qualitative study demonstrated challenges associated with a diagnosis of LQTS and risk of sudden cardiac death (Andersen et al. 2008). Those with early and gradual experience with LQTS reported less worry, but their main concern was fear for their children or grandchildren. Further, there was frustration with the limited understanding and knowledge among health professionals, in some cases providing erroneous treatment advice.

\section{DECISION-MAKING REGARDING IMPLANTABLE CARDIOVERTER DEFIBRILLATOR THERAPY}

Current knowledge about risk factors predisposing to sudden cardiac death is incomplete. Considering that the incidence of sudden cardiac death is very low, the number of patients who undergo implantation of an ICD is proportionately large. Managing risk of sudden cardiac death presents novel issues, particularly among those with heritable cardiovascular disease in which patients are often young. Given that, in most cases, prolonged ventricular arrhythmias are fatal, with little likelihood of a second chance to reconsider the management strategy, the stakes for making the correct clinical decision are high. Inherently, sudden cardiac death is an unpredictable event, often described as a moment in time. Although a patient may have been a regular runner for most of his or her life, why on one particular early morning run he or she suffered a sudden cardiac arrest is most often unknown.

The decision to undergo ICD implantation is often one the patient feels they have little control over. For example, some patients will experience an unexplained syncope and find themselves in the hospital with the decision to have an ICD seeming like an urgent and necessary next step in their management. They may later question whether the ICD was needed (Ingles et al. 2013a). Facilitating patients' efforts to weigh the benefits and potential harms of this therapy is an important component of cardiac genetic counseling (Ingles et al. 2011). Prevention of sudden cardiac death is the goal; however, being aware of the potential for low psychological well-being, inappropriate shocks, regular and ongoing device checks, and complications such as infection and device issues including lead fractures are important risks for patients to give their full consideration.

Shared decision-making as a model for deliberation over ICD recommendations has gained favor in the literature (Lewis et al. 2018). Shared decision-making in this setting includes ensuring patient values and preferences are explored and considered. One qualitative study assessed decision-making processes of patients receiving an ICD for any cardiac condition (Carroll et al. 2013). The decision-making process about the ICD was strongly influenced by the clinician's recommendation and a new awareness of the risk of sudden cardiac death. Another qualitative interview study with cardiologists and patients on their perceptions of the ICD decision-making process found that cardiologists consistently emphasized the benefits of an ICD, whereas discussion of risks was variable (Matlock et al. 2011). In contrast, many patients agreed to the ICD on the advice of their clinician without questioning the risks. Those who declined an ICD were unconvinced the ICD was necessary or believed the risks outweighed the likelihood of sudden cardiac death. These studies highlight the critical need for accurate communication of the uncertain and incremental risk of sudden cardiac death balanced with the potential risks of having an ICD.

\section{LIVING WITH AN IMPLANTABLE CARDIOVERTER DEFIBRILLATOR}

For those who choose to receive an ICD, overwhelmingly the psychological and social outcomes are favorable (Sweeting et al. 2017; Maron et al. 2018). Yet, there are certain patients who 
J. Ingles

do not fare as well and would benefit from psychological counseling. In the broader cardiovascular disease literature, patients who receive an ICD at younger age and who receive more shocks from their device are at greater risk of poor psychological outcomes (Sears and Conti 2002). The cardiac genetic counselors play an important role in this setting, in collaboration with clinical psychologists when greater support is needed (Ingles et al. 2011; Caleshu et al. 2016).

For those with inherited cardiovascular diseases, adjusting to life with an ICD can pose additional challenges. James et al. (2012) reported the experiences of patients with a diagnosis of arrhythmogenic right ventricular cardiomyopathy (ARVC) after a mean followup of $3 \mathrm{yr}$, finding healthy adaptation to the device overall. Despite this, body image concerns were markedly elevated and many reported device-related psychological distress-in particular, the younger patients. Among those with ARVC, having an ICD shock, younger age, poor functional capacity, and shorter time since implant all predicted greater device-specific distress, and poor adjustment was associated with greater reported anxiety and depressive symptoms (James et al. 2012). In a cohort of patients with catecholaminergic polymorphic ventricular tachycardia (CPVT) who had an ICD, those who were younger were more likely to report device-related distress and shock anxiety and even greater body image concerns than the ARVC cohort described above (Richardson et al. 2018).

Anxiety about experiencing a shock is an important consideration, as more shocks have consistently been shown to be associated with lower psychological functioning (Perini et al. 2017). In one study, one-third of patients with hereditary cardiovascular disease who received a shock from their ICD reported symptoms of posttraumatic stress (Ingles et al. 2013a). The most endorsed items on the Impact of Events Scale-Revised (IES-R) were "I tried not to think about it" and "I avoided letting myself get upset when I thought about it or was reminded of it," both of which reflect avoidance. Among the female patients, approximately half reported clin- ically relevant posttraumatic stress symptoms Another study showed disparity in psychological functioning by sex, with female ARVC patients more likely to report anxiety relating to shocks (Rhodes et al. 2017).

In cardiac genetic counseling, there is an appreciation of the potential psychological consequences of an ICD that is critical to empathizing with patients and providing psychotherapeutic counseling. In a clinical setting in which busy clinicians are working to manage clinical symptoms, experienced cardiac genetic counselors who explore ICD adjustment and fears of sudden cardiac death with patients and encourage discussion of any perceived psychological distress are likely to engage in a therapeutic relationship in which psychological well-being is shared and assessed. When marked anxiety or posttraumatic stress are suspected, intervention with a clinical psychologist to manage these responses is timely and important and highlights the health benefits of established multidisciplinary networks (Caleshu et al. 2016).

\section{SPORTS RESTRICTIONS}

Physical inactivity is a major determinant of poor health outcomes, recognized as the fourth leading cause of death worldwide (Kohl et al. 2012). Among inherited cardiovascular diseases, because of the observed high incidence of cardiac events occurring during exercise (Maron et al. 2014), exclusion from high-level or competitive sports applies for essentially every patient. Two unfavorable outcomes tend to follow this guidance. The first is that the patient overinterprets this recommendation and subsequently engages in little or no physical activity, increasing risk of weight gain, risk of developing other chronic diseases, and risk of lower quality of life. Alternatively, they may disregard the recommendation and continue high-level competitive sports; this occurs most often when the patient was an avid athlete prior to diagnosis.

Managing the former situation is perhaps a more common occurrence in the inherited cardiovascular clinic and likely a reflection of fear of precipitating ventricular arrhythmias and an 
Psychological Issues with Inherited Cardiovascular Diseases

overall reluctance to meet recommended physical activity guidelines among the general population. Physical inactivity has been reported in $>50 \%$ of patients with HCM (Sweeting et al. 2016), and HCM patients are less active overall than their general population counterparts (Reineck et al. 2013). Factors associated with physical inactivity include perceived barriers such as pain and injury/disability and older age (Sweeting et al. 2016). Most patients report purposeful reduction in physical activity due to their diagnosis of HCM, and less time in physical activity is associated with a negative impact on psychological well-being (Reineck et al. 2013). Interest in interventions to encourage safe increases in exercise capacity and increase overall time spent being physically active were motivation for two recently published trials. One randomized controlled trial investigated moderate-intensity training on peak oxygen consumption in HCM patients, showing overall improvement in exercise capacity following a 16-week training program, with no adverse events, such as arrhythmias, reported (Saberi et al. 2017). Another study used a control-theory approach to increase physical activity in HCM patients, incorporating motivational interviewing (Sweeting et al. 2018). Although the primary outcome of an increase in purposeful physical activity was not demonstrated, secondary end points relating to psychosocial outcomes such as health-related quality of life, self-efficacy, and perceived barriers to exercise were significantly improved.

For athletes who are diagnosed with an inherited cardiovascular disease, adopting the recommended lifestyle changes and subsequent adjustment to a new life can be profoundly challenging. Many individuals have built their identity around their athletic ability, and for some it has become a career. As such, the sudden loss of rigorous exercise results in grief. Just as patient acceptance and adherence to prescribed medical therapy relies on person-centered factors, such as understanding the necessity of the recommendation and perceived beliefs, discussion with athletes regarding sports participation may benefit from a similar approach. One study investigated athletes diagnosed with $\mathrm{HCM}$ and reported most found it difficult to adapt to the exercise restrictions (Luiten et al. 2016). Those who reported greater negative psychological impact had a history of elite or competitive sports participation, identified as an athlete, and spent less time exercising since their diagnosis. Having friends and family participate with them in lower-intensity exercise was identified as something that helped them cope with the restrictions. A qualitative study explored perspectives of individuals with HCM and LQTS who continue to exercise against current recommendations and found many did make important modifications to their exercise program over time (Subas et al. 2019). The value of a shared decision-making model in which the athlete's preferences are considered may be beneficial to addressing exercise restrictions. Genetic counselors can be integral in facilitating decision-making and adaptation about sports participation and exercise restrictions and in supporting and motivating physically inactive patients to meet recommended exercise targets.

\section{GRIEF AFTER SUDDEN CARDIAC DEATH}

In the inherited cardiovascular clinic, the families who experience the sudden and unexpected death of a previously healthy young relative present the greatest challenges. Sudden cardiac death in the young $(<35 \mathrm{yr})$ occurs at an incidence of $\sim 1.3$ per 100,000 persons, and $40 \%$ of cases will remain unexplained even after comprehensive postmortem examination (Bagnall et al. 2016). Inherited cardiomyopathies will often be identifiable at postmortem examination, because they result in structural disease. However, inherited arrhythmia syndromes, primarily diagnosed on electrocardiogram in living patients, will leave little evidence of pathophysiological changes at postmortem (Semsarian et al. 2015). In these cases, the presenting symptom can be sudden death, with no premorbid diagnosis, and those remaining unexplained at postmortem are presumed due to an inherited cardiac arrhythmia.

The grief experienced by families in this setting can be profound (Ingles and James 2017). Grief is a normal response to a loss and a process 
J. Ingles

of coming to terms with a new reality. It is experienced differently among individuals, but can include disbelief, yearning, anger, sadness, and eventually acceptance (Maciejewski et al. 2007). Kübler-Ross and Kessler (2005) wrote: "The reality is that you will grieve forever. You will not 'get over' the loss of a loved one; you will learn to live with it. You will heal and you will rebuild yourself around the loss you have suffered. You will be whole again but you will not be the same. Nor should you be the same, nor would you want to." In $\sim 7 \%$ of bereaved individuals, grief does not progress as expected, essentially resulting in the individual becoming "stuck." This is known as prolonged or complicated grief, characterized by intense yearning and an inability to imagine a new life without their loved one more than 6-12 mo after the death (Simon 2013). Prolonged grief requires intervention by a clinical psychologist or psychiatrist and poses greater risk of adverse health outcomes, suicide, and comorbid psychological conditions such as depression and posttraumatic stress disorder (Prigerson et al. 1997). Factors related to experiencing prolonged grief include being female, the nature of the relationship to the deceased, sudden and unexpected deaths, and poor understanding of the circumstances of the death, among other factors (Fujisawa et al. 2010).

The largest study to quantify psychological difficulties among first-degree relatives of a decedent in which the death was considered due to an inherited cardiovascular disease found almost $50 \%$ reported clinically significant posttraumatic stress symptoms or prolonged grief (Ingles et al. 2016). Specifically, 21\% reported prolonged grief, including 36\% of mothers of the decedent and $42 \%$ of those who witnessed the death. Posttraumatic stress symptoms were reported by $44 \%$ overall, including $59 \%$ of mothers of the decedent and $67 \%$ of those who witnessed the death (Fig. 2A). Witnessing the death or discovering the decedents body was associated with a four to five times greater risk of prolonged grief or posttraumatic stress symptoms. These findings are in contrast to a growing body of literature around family-witnessed resuscitation efforts by emergency medical services, which suggest this may provide positive psychological benefits (Robinson et al. 1998; Jabre et al. 2013). Although witnessing resuscitation may be beneficial for families when an older relative suffers a cardiac arrest, when the relative is a young person, witnessing the resuscitation ef forts and discovery of the body are the highest risk factors for poor psychological outcomes.

Another study investigating psychological well-being in families after a young sudden cardiac death showed that $>50 \%$ reported clinically significant symptoms of anxiety, on average $4 \mathrm{yr}$ after the death (Yeates et al. 2013). A qualitative analysis in the same study reported numerous factors that helped or hindered participants' ability to cope after the death (Fig. 2B). Experiences of relatives attending a specialized multidisciplinary clinic in the Netherlands identified key reasons for attending the clinic included a need to understand the cause of death and to prevent another sudden cardiac death occurring in the family (van der Werf et al. 2014). Indeed, these study outcomes reflect the overwhelming concerns expressed by relatives attending following a sudden death.

Practically, for a cardiac genetic counselor seeing families after a young sudden cardiac death, ensuring the family has the opportunity for appropriate clinical management, genetic investigations, and psychological counseling is critical. In the current clinic models for cardiovascular genetics, there can be a tendency to focus on the clinical and genetic concerns; however, based on the evidence and experiences of specialized clinics, psychological counseling should be offered to all family members (Caleshu et al. 2016; Ingles et al. 2016; Ingles and James 2017). Recognizing that in many cases these families are unlikely to encounter other health professionals following the death, the cardiologist and genetic counselor must be strong advocates for addressing psychological needs and feel comfortable discussing the family members' well-being, community support, and coping effectiveness. With growing interest in the postmortem "molecular autopsy" (genetic testing of postmortem DNA), cardiac genetic counselors must also work to ensure we limit potential harms of this technology in this vul- 
Posttraumatic stress symptoms

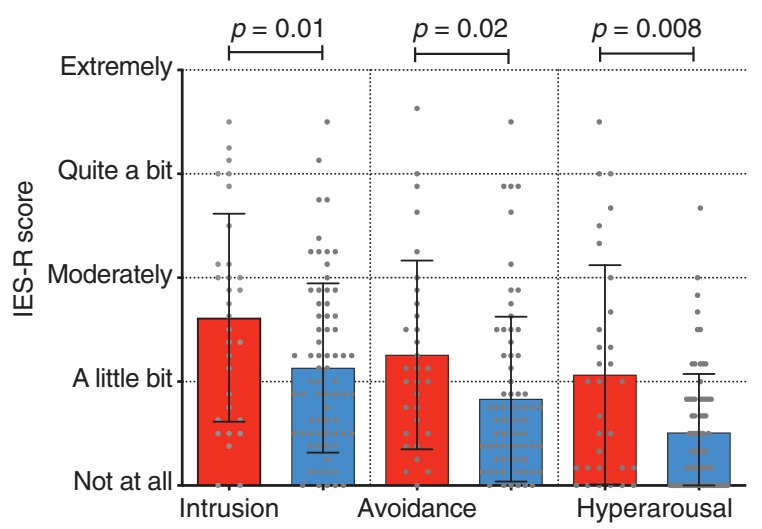

Witnessed death $\quad \square$ Did not witness

\section{B}

"Finding out that I passed on the mutation to him is probably the second hardest event of my life." [Mother of decedent]

"It is such a shock when the fittest and youngest member of your family dies suddenly. It changes your life instantly and my parents have never been the same." [Sister of decedent]

"My biggest fear is that it may happen to my other children and there doesn't seem to be a thing I can do about it." [Father of decedent]

"A's [son] passing has been the most difficult event that I have ever had to contend with in my life as I'm sure it is for any parent in the same situation." [Mother of decedent]

Figure 2. Psychological consequences for family members following the sudden cardiac death of a young relative. (A) There was a greater risk of posttraumatic stress symptoms among first-degree relatives who witnessed the death or discovered the decedent's body. This was true across the three subdomains of the impact of events scale (IES-R) (Ingles et al. 2016). (B) Key quotes from a qualitative study illustrating common difficulties reported by family members, including genetic guilt, shock, disbelief, and fear for remaining children (Yeates et al. 2013).

nerable patient group. This includes pretest genetic counseling that sets realistic expectations about the likelihood of a conclusive result and careful review of variants to avoid misclassification. A variant of uncertain significance will be identified in $>40 \%$ of postmortem cases, and a causative variant identified in only $\sim 10 \%$ (Lahrouchi et al. 2017). How a family facing profound psychological challenges can understand and adapt to the high degree of uncertainty this testing often yields is not well understood, but it has the potential to inflict harm. A small 2018 study showed that more than one-third of firstdegree relatives of a young victim of sudden cardiac death showed difficulty adapting psychologically to the postmortem genetic test information (Bates et al. 2019). Further research to establish an effective method to integrate psychotherapeutic counseling into the cardiac clinic setting is needed.

\section{CONCLUSION}

Many challenges exist for patients with inherited cardiovascular diseases and their at-risk relatives. Research-focused genetic counselors have already played an important role in understanding the issues faced by this patient 
J. Ingles

population, which offers evidence to inform development of more effective management approaches. Although this review has focused on those aspects of care relating to a diagnosis, managing sudden cardiac death risk, ICD therapy, and sudden cardiac death, numerous other challenges remain, particularly related to genetic testing. For the genetic counselor, always being mindful and aware of psychological challenges that diminish our patient's quality of life is paramount and will ultimately help to improve overall management and care of families with heritable cardiovascular diseases.

\section{ACKNOWLEDGMENTS}

J.I. is the recipient of a National Health and Medical Research Council Career Development Fellowship (APP1162929). The author declares there are no conflicts of interest.

\section{REFERENCES}

Andersen J, Øyen N, Bjorvatn C, Gjengedal E. 2008. Living with long QT syndrome: a qualitative study of coping with increased risk of sudden cardiac death. J Genet Couns 17: 489-498. doi:10.1007/s10897-008-9167-y

Bagnall RD, Weintraub RG, Ingles J, Duflou J, Yeates L, Lam L, Davis AM, Thompson T, Connell V, Wallace J, et al. 2016. A prospective study of sudden cardiac death among children and young adults. N Engl J Med 374: 2441-2452. doi:10.1056/NEJMoa1510687

Bates K, Sweeting J, Yeates L, McDonald K, Semsarian C Ingles J. 2019. Psychological adaptation to molecular autopsy findings following sudden cardiac death in the young. Genet Med 21: 1452-1456. doi:10.1038/s41436018-0338-4

Benjamin EJ, Muntner P, Alonso A, Bittencourt MS, Callaway CW, Carson AP, Chamberlain AM, Chang AR Cheng S, Das SR, et al. 2019. Heart disease and stroke statistics-2019 update: a report from the American Heart Association. Circulation 139: e56-e528. doi:10 .1161/CIR.0000000000000659

Burns C, McGaughran J, Davis A, Semsarian C, Ingles J. 2016. Factors influencing uptake of familial long QT syndrome genetic testing. Am JMed Genet A 170A: 418-425. doi:10.1002/ajmg.a.37455

Caleshu C, Kasparian NA, Edwards KS, Yeates L, Semsarian C, Perez M, Ashley E, Turner CJ, Knowles JW, Ingles J. 2016. Interdisciplinary psychosocial care for families with inherited cardiovascular diseases. Trends Cardiovasc Med 26: 647-653. doi:10.1016/j.tcm.2016.04.010

Carroll SL, Strachan PH, de Laat S, Schwartz L, Arthur HM 2013. Patients' decision making to accept or decline an implantable cardioverter defibrillator for primary preven- tion of sudden cardiac death. Health Expect 16: 69-79. doi:10.1111/j.1369-7625.2011.00703.x

Chockalingam P, Crotti L, Girardengo G, Johnson JN, Harris KM, van der Heijden JF, Hauer RN, Beckmann BM, Spazzolini C, Rordorf R, et al. 2012. Not all $\beta$-blockers are equal in the management of long QT syndrome types 1 and 2: higher recurrence of events under metoprolol. J Am Coll Cardiol 60: 2092-2099. doi:10.1016/j.jacc.2012.07 .046

Christiaans I, van Langen IM, Birnie E, Bonsel GJ, Wilde AA, Smets EM. 2009. Quality of life and psychological distress in hypertrophic cardiomyopathy mutation carriers: a cross-sectional cohort study. Am J Med Genet A 149A: 602-612. doi:10.1002/ajmg.a.32710

Connors E, Jeremy RW, Fisher A, Sharpe L, Juraskova I. 2015. Adjustment and coping mechanisms for individuals with genetic aortic disorders. Heart Lung Circ 24: 1193-1202. doi:10.1016/j.hlc.2015.05.003

Farnsworth MM, Fosyth D, Haglund C, Ackerman MJ. 2006. When I go in to wake them ... I wonder: parental perceptions about congenital long QT syndrome. J Am Acad Nurse Pract 18: 284-290. doi:10.1111/j.1745-7599.2006 .00132.x

Fujisawa D, Miyashita M, Nakajima S, Ito M, Kato M, Kim Y. 2010. Prevalence and determinants of complicated grief in general population. J Affect Disord 127: 352-358. doi:10.1016/j.jad.2010.06.008

Hamang A, Eide GE, Nordin K, Rokne B, Bjorvatn C, Øyen N. 2010. Health status in patients at risk of inherited arrhythmias and sudden unexpected death compared to the general population. BMC Med Genet 11: 27. doi:10 .1186/1471-2350-11-27

Hendriks KS, Grosfeld FJ, van Tintelen JP, van Langen IM, Wilde AA, van den Bout J, ten Kroode HF. 2005. Can parents adjust to the idea that their child is at risk for a sudden death?: psychological impact of risk for long QT syndrome. Am J Med Genet A 138A: 107-112. doi:10 .1002/ajmg.a.30861

Ingles J, James C. 2017. Psychosocial care and cardiac genetic counseling following sudden cardiac death in the young. Prog Pediatr Cardiol 45: 31-36. doi:10.1016/j.ppedcard 2017.03.001

Ingles J, Yeates L, Semsarian C. 2011. The emerging role of the cardiac genetic counselor. Heart Rhythm 8: 19581962. doi:10.1016/j.hrthm.2011.07.017

Ingles J, Sarina T, Kasparian N, Semsarian C. 2013a. Psychological wellbeing and posttraumatic stress associated with implantable cardioverter defibrillator therapy in young adults with genetic heart disease. Int J Cardiol 168: 3779-3784. doi:10.1016/j.ijcard.2013.06.006

Ingles J, Yeates L, Hunt L, McGaughran J, Scuffham PA, Atherton J, Semsarian C. 2013b. Health status of cardiac genetic disease patients and their at-risk relatives. Int J Cardiol 165: 448-453. doi:10.1016/j.ijcard.2011.08 .083

Ingles J, Johnson R, Sarina T, Yeates L, Burns C, Gray B, Ball K, Semsarian C. 2015. Social determinants of health in the setting of hypertrophic cardiomyopathy. Int J Cardiol 184: 743-749. doi:10.1016/j.ijcard.2015.03.070

Ingles J, Spinks C, Yeates L, McGeechan K, Kasparian N, Semsarian C. 2016. Posttraumatic stress and prolonged grief after the sudden cardiac death of a young relative. 
JAMA Intern Med 176: 402-405. doi:10.1001/jamai nternmed.2015.7808

Jabre P, Belpomme V, Azoulay E, Jacob L, Bertrand L, Lapostolle F, Tazarourte K, Bouilleau G, Pinaud V, Broche C, et al. 2013. Family presence during cardiopulmonary resuscitation. N Engl J Med 368: 1008-1018. doi:10.1056/ NEJMoa1203366

James CA, Tichnell C, Murray B, Daly A, Sears SF, Calkins H. 2012. General and disease-specific psychosocial adjustment in patients with arrhythmogenic right ventricular dysplasia/cardiomyopathy with implantable cardioverter defibrillators: a large cohort study. Circ Cardiovasc Genet 5: 18-24. doi:10.1161/CIRCGENETICS.111 .960898

Jin J, Sklar GE, Min Sen Oh V, Chuen Li S. 2008. Factors affecting therapeutic compliance: a review from the patient's perspective. Ther Clin Risk Manag 4: 269-286. doi:10.2147/TCRM.S1458

Kohl HW III, Craig CL, Lambert EV, Inoue S, Alkandari JR, Leetongin G, Kahlmeier S, Lancet Physical Activity Series Working Group. 2012. The pandemic of physical inactivity: global action for public health. Lancet 380: 294-305. doi:10.1016/S0140-6736(12)60898-8

Kübler-Ross E, Kessler D. 2005. On grief and grieving. Finding the meaning of grief through the five stages of loss. Simon \& Schuster, New York.

Lahrouchi N, Raju H, Lodder EM, Papatheodorou E, Ware JS, Papadakis M, Tadros R, Cole D, Skinner JR, Crawford J, et al. 2017. Utility of post-mortem genetic testing in cases of Sudden Arrhythmic Death Syndrome. J Am Coll Cardiol 69: 2134-2145. doi:10.1016/j.jacc.2017.02 .046

Lewis KB, Carroll SL, Birnie D, Stacey D, Matlock DD. 2018. Incorporating patients' preference diagnosis in implantable cardioverter defibrillator decision-making: a review of recent literature. Curr Opin Cardiol 33: 42-49. doi:10 .1097/HCO.0000000000000464

Luiten RC, Ormond K, Post L, Asif IM, Wheeler MT, Caleshu C. 2016. Exercise restrictions trigger psychological difficulty in active and athletic adults with hypertrophic cardiomyopathy. Open Heart 3: e000488. doi:10.1136/ openhrt-2016-000488

Maciejewski PK, Zhang B, Block SD, Prigerson HG. 2007. An empirical examination of the stage theory of grief. $J$ Am Med Assoc 297: 716-723. doi:10.1001/jama.297.7.716

Maron BJ, Haas TS, Murphy CJ, Ahluwalia A, RuttenRamos S. 2014. Incidence and causes of sudden death in U.S. college athletes. J Am Coll Cardiol 63: 16361643. doi:10.1016/j.jacc.2014.01.041

Maron BJ, Casey SA, Olivotto I, Sherrid MV, Semsarian C, Autore C, Ahmed A, Boriani G, Francia P, Winters SL, et al. 2018. Clinical course and quality of life in high-risk patients with hypertrophic cardiomyopathy and implantable cardioverter-defibrillators. Circ Arrhythm Electrophysiol 11: e005820. doi:10.1161/CIRCEP .117 .005820

Matlock DD, Nowels CT, Masoudi FA, Sauer WH, Bekelman DB, Main DS, Kutner JS. 2011. Patient and cardiologist perceptions on decision making for implantable cardioverter-defibrillators: a qualitative study. Pacing Clin Electrophysiol 34: 1634-1644. doi:10.1111/j.1540-8159.2011 .03237.x
McGovern PG, Pankow JS, Shahar E, Doliszny KM, Folsom AR, Blackburn H, Luepker RV. 1996. Recent trends in acute coronary heart disease-mortality, morbidity, medical care, and risk factors. The Minnesota Heart Survey Investigators. N Engl J Med 334: 884-890. doi:10.1056/ NEJM199604043341403

O'Donovan CE, Waddell-Smith KE, Skinner JR, Broadbent E. 2018. Predictors of $\beta$-blocker adherence in cardiac inherited disease. Open Heart 5: e000877. doi:10.1136/ openhrt-2018-000877

Ormondroyd E, Oates S, Parker M, Blair E, Watkins H. 2014. Pre-symptomatic genetic testing for inherited cardiac conditions: a qualitative exploration of psychosocial and ethical implications. Eur J Hum Genet 22: 88-93. doi:10 .1038/ejhg.2013.81

Perini AP, Kutyifa V, Veazie P, Daubert JP, Schuger C, Zareba W, McNitt S, Rosero S, Tompkins $\mathrm{C}$, Padeletti L, et al. 2017. Effects of implantable cardioverter/defibrillator shock and antitachycardia pacing on anxiety and quality of life: a MADIT-RIT substudy. Am Heart J 189: 75-84. doi:10.1016/j.ahj.2017.03.009

Petrie KJ, Perry K, Broadbent E, Weinman J. 2012. A text message programme designed to modify patients' illness and treatment beliefs improves self-reported adherence to asthma preventer medication. Br J Health Psychol 17: 7484. doi:10.1111/j.2044-8287.2011.02033.x

Prigerson HG, Bierhals AJ, Kasl SV, Reynolds CF III, Shear MK, Day N, Beery LC, Newsom JT, Jacobs S. 1997. Traumatic grief as a risk factor for mental and physical morbidity. Am J Psychiatry 154: 616-623. doi:10.1176/ajp.154 .5 .616

Priori SG, Blomström-Lundqvist C, Mazzanti A, Blom N, Borggrefe M, Camm J, Elliott PM, Fitzsimons D, Hatala R, Hindricks G, et al. 2015. 2015 ESC Guidelines for the management of patients with ventricular arrhythmias and the prevention of sudden cardiac death: the Task Force for the Management of Patients with Ventricular Arrhythmias and the Prevention of Sudden Cardiac Death of the European Society of Cardiology (ESC). Endorsed by Association for European Paediatric and Congenital Cardiology (AEPC). Eur Heart J 36: 2793-2867. doi:10.1093/eurheartj/ehv316

Reineck E, Rolston B, Bragg-Gresham JL, Salberg L, Baty L, Kumar S, Wheeler MT, Ashley E, Saberi S, Day SM. 2013. Physical activity and other health behaviors in adults with hypertrophic cardiomyopathy. Am J Cardiol 111: 10341039. doi:10.1016/j.amjcard.2012.12.018

Rhodes AC, Murray B, Tichnell C, James CA, Calkins H, Sears SF. 2017. Quality of life metrics in arrhythmogenic right ventricular cardiomyopathy patients: the impact of age, shock and sex. Int J Cardiol 248: 216-220. doi:10 $.1016 /$ j.ijcard.2017.08.026

Richardson E, Spinks C, Davis A, Turner C, Atherton J, McGaughran J, Semsarian C, Ingles J. 2018. Psychosocial implications of living with catecholaminergic polymorphic ventricular tachycardia in adulthood. J Genet Couns 27: 549-557. doi:10.1007/s10897-017-0152-1

Robinson SM, Mackenzie-Ross S, Campbell Hewson GL, Egleston CV, Prevost AT. 1998. Psychological effect of witnessed resuscitation on bereaved relatives. Lancet 352: 614-617. doi:10.1016/S0140-6736(97)12179-1 
J. Ingles

Saberi S, Wheeler M, Bragg-Gresham J, Hornsby W, Agarwal PP, Attili A, Concannon M, Dries AM, Shmargad Y, Salisbury H, et al. 2017. Effect of moderate-intensity exercise training on peak oxygen consumption in patients with hypertrophic cardiomyopathy: a randomized clinical trial. J Am Med Assoc 317: 1349-1357. doi:10.1001/ jama.2017.2503

Sears SF Jr, Conti JB. 2002. Quality of life and psychological functioning of ICD patients. Heart 87: 488-493. doi:10 $.1136 /$ heart.87.5.488

Semsarian C, Ingles J, Wilde AA. 2015. Sudden cardiac death in the young: the molecular autopsy and a practical approach to surviving relatives. Eur Heart J 36: 1290-1296. doi:10.1093/eurheartj/ehv063

Simon NM. 2013. Treating complicated grief. J Am Med Assoc 310: 416-423. doi:10.1001/jama.2013.8614

Subas T, Luiten R, Hanson-Kahn A, Wheeler M, Caleshu C. 2019. Evolving decisions: perspectives of active and athletic individuals with inherited heart disease who exercise against recommendations. J Genet Couns 28: 119-129. doi: 10.1007/s10897-018-0297-6.

Sweeting J, Ingles J, Timperio A, Patterson J, Ball K, Semsarian C. 2016. Physical activity in hypertrophic cardiomyopathy: prevalence of inactivity and perceived barriers. Open Heart 3: e000484. doi:10.1136/openhrt-2016-000484
Sweeting J, Ball K, McGaughran J, Atherton J, Semsarian C, Ingles J. 2017. Impact of the implantable cardioverter defibrillator on confidence to undertake physical activity in inherited heart disease: a cross-sectional study. Eur J Cardiovasc Nurs 16: 742-752. doi:10.1177/1474 515117715760

Sweeting J, Ingles J, Ball K, Semsarian C. 2018. A control theory-based pilot intervention to increase physical activity in patients with hypertrophic cardiomyopathy. Am J Cardiol 122: 866-871. doi:10.1016/j.amjcard.2018 .05 .023

van der Werf C, Onderwater AT, van Langen IM, Smets EM. 2014. Experiences, considerations and emotions relating to cardiogenetic evaluation in relatives of young sudden cardiac death victims. Eur J Hum Genet 22: 192-196. doi:10.1038/ejhg.2013.126

Watkins H, Ashrafian H, Redwood C. 2011. Inherited cardiomyopathies. $N$ Engl J Med 364: 1643-1656. doi:10 .1056/NEJMra0902923

Yeates L, Hunt L, Saleh M, Semsarian C, Ingles J. 2013. Poor psychological wellbeing particularly in mothers following sudden cardiac death in the young. Eur J Cardiovasc Nurs 12: 484-491. doi:10.1177/147451511 3485510 


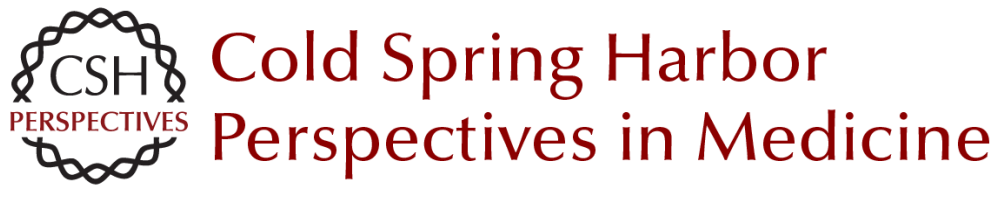

\section{Psychological Issues in Managing Families with Inherited Cardiovascular Diseases}

Jodie Ingles

Cold Spring Harb Perspect Med 2020; doi: 10.1101/cshperspect.a036558 originally published online September 23, 2019

Subject Collection Genetic Counseling: Clinical Practice and Ethical Considerations

Genetic Risk Assessment in Psychiatry

Holly Landrum Peay

Birds of a Feather? Genetic Counseling, Genetic

Testing, and Humanism

Robert Resta

Bridging the Gap between Scientific Advancement and Real-World Application: Pediatric Genetic

Counseling for Common Syndromes and

Single-Gene Disorders

Julie A. McGlynn and Elinor Langfelder-Schwind

Genetic Counseling, Personalized Medicine, and

Precision Health

Erica Ramos

Tumor-Based Genetic Testing and Familial Cancer

Risk

Andrea Forman and Jilliane Sotelo

A Person-Centered Approach to Cardiovascular Genetic Testing

Julia Platt

Evidence-Based Genetic Counseling for

Psychiatric Disorders: A Road Map Jehannine C. Austin

Supporting Patient Autonomy and Informed

Decision-Making in Prenatal Genetic Testing

Katie Stoll and Judith Jackson
Impact of Emerging Technologies in Prenatal

Genetic Counseling

Blair Stevens

Genetic Counseling and Assisted Reproductive

Technologies

Debra Lilienthal and Michelle Cahr

Evolving Roles of Genetic Counselors in the

Clinical Laboratory

Megan T. Cho and Carrie Guy

Psychological Issues in Managing Families with Inherited Cardiovascular Diseases Jodie Ingles

Informed Consent in the Genomics Era Shannon Rego, Megan E. Grove, Mildred K. Cho, et al.

Predictive Genetic Counseling for

Neurodegenerative Diseases: Past, Present, and

Future Jill S. Goldman

Cancer Genetic Counseling--Current Practice and

Future Challenges Jaclyn Schienda and Jill Stopfer

Regulating Preimplantation Genetic Testing across the World: A Comparison of International

Policy and Ethical Perspectives

Margaret E.C. Ginoza and Rosario Isasi

For additional articles in this collection, see http://perspectivesinmedicine.cshlp.org/cgi/collection/ 